\title{
Eye tracking jako metoda stwarzająca nowe możliwości w urbanistycznych badaniach eksperymentalnych
}

\author{
Wojciech Kocki, Bartłomiej Kwiatkowski
}

Faculty of Civil Engineering and Architecture Department of Architecture and Urban Planning, Lublin University of Technology

\section{Magdalena Borys, Mariusz Dzieńkowski}

Institute of Computer Science, Faculty of Electrical Engineering and Computer Science, Lublin University of Technology

\section{Wioletta Tuszyńska-Bogucka}

Institute Of Psychology and Human Sciences, University of Economics and Innovations of Lublin

\section{Jacek Bogucki \\ Clinical Genetics Department, Medical University Of Lublin}

\section{Jarosław Pełka}

Addiction Treatment Center of Lublin

\begin{abstract}
Streszczenie: Eye tracking, a więc metoda badania aktywności okulomotorycznej wśród rozlicznych zastosowań stwarza także unikalną możliwość badań w zakresie urbanistyki eksperymentalnej. Dzięki dużej liczbie danych jakie dostarcza ta metoda przybliża ona nie tylko poznanie sposobu patrzenia na budynki i otaczającą je przestrzeń, ale także reakcji emocjonalnych, jakie budzą one w odbiorcy, przyczyniając się do tworzenia tzw. przyjaznego środowiska architektonicznego. Przy założeniu interdyscyplinarnej współpracy i dyskusji specjalistów z dziedzin psychologii, architektury oraz informatyki wydaje się, że współczesna okulografia może stać się narzędziem harmonijnie scalającym działania, w efekcie których zwiększa się zarówno wiedza, dotycząca efektu wpływu przestrzeni architektonicznej na człowieka, jak i takiego jej zaplanowania, aby aktywnie przyczyniała się ona do optymalizacji warunków życia współczesnego człowieka w oparciu o obiektywne dane.
\end{abstract}

\section{Wprowadzenie. Eye tracking wczoraj i dziś}

Zastosowanie metod neuronauki do analizy i rozumienia ludzkich zachowań w kontrolowanych środowiskach lub laboratoriach zyskało ostatnio wzmożoną uwagę badaczy. Jest to spowodowane faktem, iż technologie śledzenia aktywności okulomotorycznej są coraz częściej wykorzystywane w przemyśle i badaniach ze względu na dostępność oraz względnie umiarkowany koszt tego rodzaju badań. Zastosowanie eyetrackingu umożliwia sprawdzenie, co angażuje wzrok człowieka, a co jest przezeń ignorowane (pomijane). W świetle tego, co dziś wiemy na temat naurobiologii człowieka powiedzieć można, że oczy oraz ich aktywność są silnie powiązane z niektórymi procesami poznawczymi (Błasiak et al., 2013¹). Rejestracja aktywności oczu może pomóc w zrozumieniu mechanizmów percepcji wizualnej, ważnej z punktu widzenia wielu ludzkich zachowań. Eye tracking 
często nazywany jest metodą śledzenia ruchu gałek ocznych, co w rzeczywistości jednak nie jest głównym celem metody, którym jest informacja o „ścieżce" wzrokowej, utworzonej w czasie wodzenia wzrokiem po oglądanym obrazie, przedmiocie - lub mówiąc ogólnie - w czasie widzenia (Duchowski, 2007²). Działanie eye trackerów w przypadku większości nowoczesnych modeli opiera się na metodzie nazywanej odbiciem rogówki (corneal reflection), polegającej na wykryciu i śledzeniu położenia i ruchów gałek ocznych. Kamera o dużej rozdzielczości wykrywa położenie źrenic, które oświetlane są niewidzialnym dla człowieka światłem podczerwonym. Podczerwień odbija się od oczu, tworząc odbicia stanowiące dobrze widoczne w źrenicach refleksy, za pomocą których można zidentyfikować miejsce, w które w danym momencie badany patrzy (Garczarek-Bąk, 2016).

Eye tracking i marketing. (Wedel, Pieters, 200833; Kaczmarek, 2012 ; Horsley, 20145; Wąsikowska, 2015 ; Garczarek-Bąk, 2016). Przykładami zastosowania eye trackingu są tu np. badania nad percepcją materiałów reklamowych, zdjęć rozmaitych produktów (np. w różnych opracowaniach), rozmieszczenia towarów, elementy wystroju skutecznie angażujące uwagę, zauważalność logo i marki, projektowane i wykonywane w celu wyjaśniania czynników, determinujących zachowania konsumenckie - decyzje zakupowe, czynniki wyborów czy prezentowane postawy (jawne i utajone). Na potrzeby tej gałęzi badań utworzono nazwę neuromarketingu (Mruk, 20087; Ohme, 2011).

Eye tracking i zdrowie. W dziedzinie medycyny i psychologii zdrowia śledzenie oczu jest wykorzystywane do badania skutków różnych chorób oraz zachowania i procesu decyzyjnego osób w różnych przypadkach związanych ze zdrowiem - stał się on narzędziem do badania wzrokowej uwagi i poznania oraz diagnozowania w różnego rodzaju procesach chorobowych (Harezlak et al., 20179; Raudonis et al., 200910; Yang et al., 2013; Garcia-Blanco et al., 2015; Gillespie-Smith, Fletcher-Watson, 2014 ${ }^{11}$ ). Interesującą ścieżkę stanowią tu także badania nad zastosowaniem okulografii do analizy danych medycznych, w tym wizualizacji kognitywnych (Pilipczuk, 2013; Pilipczuk, Eidenzon, 2013 ${ }^{12}$ ). W ostatnim czasie na szczególną uwagę zasługuje także użycie eyetrackingu w badaniach nad metodami symulacyjnymi w medycynie (Law et al., 2004 ${ }^{13}$; Wilson et al., $2011^{14}$ ).

Eye tracking i ergonomia. Do tej pory ergonomia, badana za pomocą eye trackerów rozumiana była głównie jako badania użyteczności (telefonów komórkowych, paneli sterowania, kokpitów, urządzeń RTV i AGD,

2 Duchowski A.T., 2007, Eye tracking methodology: Theory and practice. Second Edition. London: Springer-Verlag.

3 Wedel M., Pieters R., 2008, A Review of Eye-Tracking Research in Marketing, [w:] Review of Marketing Research, Malhotra N.K. (eds.), M.E. Sharpe, Inc., Armonk, New York, London, England.

4 Kaczmarek M., 2012, Mocne i słabe strony eye trackingu jako metody badania zachowań nabywców, [w:] Foresight w praktyce zarządzania przedsiębiorstwem. Analizy i studia przypadków, Borodako, K., Nowosielski M. (red.), Instytut Zachodni, Poznań.

5 Horsley M., 2014, Eye Tracking as a Research Method in Social and Marketing Applications, [in:] Current Trends in Eye Tracking Research Horsley M., Toon N., Knight B., Reilly R. (eds.), Springer International Publishing, Switzerland.

6 Wąsikowska B, Eye tracking w badaniach marketingowych. Zeszyty Naukowe Uniwersytetu Szczecińskiego Studia Informatica 2016, 863(36): 177-192.

7 H. Mruk, Neuromarketing jako obszar badań interdyscyplinarnych. W: Współczesny marketing. Trendy. Działania, G. Sobczyk (red.), PWE, Warszawa 2008, s. 97

8 R.K. Ohme, Biometryczny przełom w marketingu. Jak dzięki wykorzystaniu badań biometrycznych podnosić skuteczność komunikacji marketingowej i budować trwałe, emocjonalne relacje z klientami, „Harvard Business Review Polska” 2011, nr 7/8.

9 Harezlak, K., Kasprowski, P., Application of eye tracking in medicine: A survey, research issues and challenges. Comput Med Imaging Graph (2017), http://dx.doi.org/10.1016/j.compmedimag.2017.04.006

10 V. Raudonis, R. Simutis, G. Narvydas, Discrete eye tracking for medical applications, 2nd International Symposium on Applied Sciences in Biomedical and Communication Technologies, 2009, s. 1-6.

11 Yang, Q., Wang, T., Su, N., Xiao, S., Kapoula, Z., 2013. Specific saccade deficits inpatients with Alzheimer's disease at mild to moderate stage and in patientswith amnestic mild cognitive impairment. Age 35 (4), 1287-1298.

Garcia-Blanco, A., Salmerón, L., Perea, M., Livianos, L., 2014. Attentional biases toward emotional images in the different episodes of bipolar disorder: an eye-tracking study. Psychiatry Res. 215 (3), 628-633.

Gillespie-Smith, K., Fletcher-Watson, S., 2014. Designing AAC systems for children with autism: evidence from eye tracking research. Augment. Altern. Commun. 30 (2), 160-171.

12 O. Pilipczuk, Zastosowanie wizualizacji kognitywnych w podejmowaniu decyzji biznesowych, w: Wiedza i technologie informacyjne: nowe trendy badań i aplikacji, red. T. Turek, D. Jelonek, WWZPCz, Częstochowa 2013, s. 86-101; O. Pilipczuk, D. Eidenzon, The application of cognitive computer graphics to economic data exploration, „Journal of Automation, Mobile Robotics \& Inteligent Systems" 2013, vol. 7(3), s. 3-9.

13 Law B, Atkins MS, Kirkpatrick AE, Lomax AJ, Mackenzie CL, Eye gaze patterns differentiate novice and experts in a virtual laparoscopic surgery training environment. Conference: Proceedings of the Eye Tracking Research \& Application Symposium, ETRA 2004, San Antonio, Texas, USA, March 22-24, 2004. Retriewed from https://www.researchgate.net/publication/220811148_Eye_gaze_patterns_differentiate_ novice_and_experts_in_a_virtual_laparoscopic_surgery_training_environment [access: 2018-11-12].

14 Wilson MR, Vine SJ, Bright E, Masters RS, Defriend D, McGrath JS. Gaze training enhances laparoscopic technical skill acquisition and multi-tasking performance: a randomized, controlled study. Surg Endosc. 2011;25(12):3731-9. 
a nawet stanowisk pracy). Testowano więc np. łatwość i intuicyjność obsługi rozmaitych urządzeń, prawidłowość urządzenia stanowisk pracy, skuteczność rozwiązań makro- i mikronawigacji sklepowej, dostępność potrzebnych elementów, ewentualne dystraktory, analizowano czytelność aplikacji internetowych, infografik, sprawdzano systemy informacji publicznej, oznakowania na drogach, rozmieszczenia elementów na kartach wyborczych, itp. Szczególną wagę mają tu też badania obciążenia zadaniowego, np. kierowców bądź pilotów (Merkisz et al., 2015 ${ }^{15}$ ).

Eye tracking i edukacja. Istnieją również prace, w których wykorzystywano eye tracking do innych celów, takich jak terapia lub poprawa edukacji (Studer et al., 201016; Manelis, Reder, 2012 ${ }^{17}$; Błasiak et al., 2013; Kraus, Horowitz-Kraus, 2014 ${ }^{18}$; Wang et al., 2014 ${ }^{19}$; Wawer, 2014 ${ }^{20}$; Piotrowska, 2014 ${ }^{21}$; Paśko, 2017), także w odniesieniu do różnych grup odbiorców (Josephson, Holmes, 200422; Tullis et al., 200723). Badania eyetrackingowe pozwalają śledzić przebieg ścieżki wzroku w czasie oglądania zarówno obrazu statycznego, jak i ruchomego, a także poszczególne etapy oraz optymalny czas rozwiązywania zadań problemowych. Na podstawie wyników analizy zapisu przemieszczania się wzroku można określić optymalny czas wyświetlania obrazu (Paśko, 2017). Wyniki badań eyetrackingowych można wykorzystać w trzech aspektach. Jednym z nich jest optymalizacja procesu uczenia się i nauczania oraz przygotowanie strategii indywidualnego oddziaływania na ucznia w tym procesie. Drugi aspekt obejmuje problematykę związaną z doborem i tworzeniem środków dydaktycznych, które będą w najbardziej optymalny sposób oddziaływać na uczących się. Po trzecie rezultaty tych badań dają możliwość wykrywania u uczniów ewentualnych dysfunkcji w procesie myślenia (Paśko, 2017²4).

Eye tracking $\boldsymbol{i}$ wsparcie osób niepełnosprawnych. Eyetracking jest techniką, za pomocą której osoby sparaliżowane mają możliwość swobodnego kontaktowania się ze światem zewnętrznym. Technologia ta oferuje wsparcie osobom niepełnosprawnym przez rozpoznanie poleceń wydawanych za pomocą wzroku: osób z zaburzeniami neurologicznymi, jak i osób z udarem mózgu, urazami mechanicznymi w obrębie głowy, szyi, tułowia i kończyn, które często zachowują poprawnie kontrolowaną aktywność wzrokową. Na podstawie rezultatów szeroko zakrojonych badań z użyciem tej metody w roku 2011 stworzono na przykład pierwszy tablet, pomagający osobom niepełnosprawnym w kontaktach z otoczeniem (Pilipczuk, 2014 ${ }^{25}$ ).

Wydaje się także, że eye tracking może być szerzej wykorzystywany w badaniach ergonomii środowiskowej، głównie w obszarze optymalizacji warunków funkcjonowania jednostek w określonych warunkach, co wyraźnie sugeruje wynikające stąd implikacje dla urbanistyki i projektowania przestrzennego (Tuszyńska-Bogucka et al., 2018).

15 Merkisz J, Markowski J, Fuć P, Galant M, Przegląd metod pomiaru obciążenia zadaniowego operatora w badaniach z wykorzystaniem symulatorów. Logistyka 2015, 3: 3188-3194.

16 Studer, B., Koeneke, S., Blum, J., Jäncke, L. (2010). The effects of practice distribution upon the regional oscillatory activity in visuomotor learning. Behavioral and Brain Functions, 6 (8).

17 Manelis, A., Reder, L.M. (2012). Procedural learning and associative memory mechanism contribute to contextual cueing: Evidence from fMRI and eye-tracking. Learning \& Memory, 19, 527-534.

18 Kraus, D., Horowitz-Kraus, T. (2014). The effect of learning on feedback - related potentials in adolescents with dyslexia: An EEG-ERP study. PLOS ONE, 9 (6)

19 Wang, H-S., Chen, Y-T., Lin, C-H. (2014). The learning benefits of using eye trackers to enhance the geospatial abilities of elementary school students. British Journal of Educational Technology, 45 (2), 340-355.

20 Wawer, R. (2014). Eyetracking w przestrzeniach edukacji medialnej. Lublin: Lubelskie Towarzystwo Naukowe.

21 Piotrowska I, Okulografia w badaniach postrzegania i konstruowania wiedzy geograficznej. Prace Komisji Edukacji Geograficznej 2014, t. 3, s. $175-189$

22 Josephson, S., Holmes, M.: Age differences in visual search for information on web pages. In: Eye Tracking Research \& Application. Proceedings of the 2004 symposium on Eye tracking research \& applications, San Antonio, TX, p. 62 (2004)

23 Tullis T.S. (2007) Older Adults and the Web: Lessons Learned from Eye-Tracking. In: Stephanidis C. (eds) Universal Acess in Human Computer Interaction. Coping with Diversity. UAHCI 2007. Lecture Notes in Computer Science, vol 4554. Springer, Berlin, Heidelberg

24 Paśko I, Eyetrackingowe badania we wczesnej edukacji przyrodniczej. Pedagogika Przedszkolna i Wczesnoszkolna 2017, 5, 2/1 (10/1): 205-215.

25 Pilipczuk O, Technologie eye-tracking w analizie danych medycznych. Roczniki Kolegium Analiz Ekonomicznych / Szkoła Główna Handlowa 2014, 35: 323-337. 


\section{Dane dostarczane dzięki użyciu eyetrackingu}

Eye tracking umożliwia bardzo precyzyjne przedstawienie zachowań gałek ocznych jednostek. W literaturze przedmiotu wyróżnia się trzy podstawowe atrybuty badań, takie jak: lokalizacja, czas trwania i ruch. Typowy pomiar eye trackingowy opiera się na analizie dwóch podstawowych aktywności narządu wzroku - ruchu gałek ocznych (sakkad) oraz ich bezruchu (fiksacji):

- fiksacji - ruchów gałek ocznych, które stabilizują siatkówkę nad nieruchomym obiektem (trwają one od 100 do 600 milisekund);

- sakkad - szybkiego przeniesienia wzroku z jednego punktu skupienia na drugi (zajmują od 20 do 40 milisekund);

- całkowitego oraz średniego czasu poświęconego na oglądanie materiału;

- ilości rewizyt - ponownego oglądania danych elementów [Duchowski 2007; Kabaja, Kruka, 2017].

Ruchy sakkadowe charakteryzują się następującymi parametrami ilościowymi: latencją, amplitudą oraz czasem trwania i prędkością. Fiksacja wzrokowa umożliwia gałkom ocznym utrzymanie obrazu nieporuszającego się obiektu w obrębie plamki żółtej poprzez minimalizację dryfu gałki ocznej. W przypadku zsunięcia się obrazu obiektu z plamki żółtej układ generuje sakkadę korekcyjną o niewielkiej amplitudzie, tzw. mikrosakkadę (Kabaja, Kruka, 2017). Zebrane podczas badania eye trackingowego dane dotyczące liczby, czasu i miejsc powstawania sakkad oraz fiksacji są podstawowym narzędziem umożliwiającym dokonanie analizy i interpretacji uzyskanych wyników. Inną formą wizualizacji i prezentacji zebranych podczas badania eye trackingowego danych są ścieżki patrzenia (mapy fiksacji). Obrazują one miejsca fiksacji wzroku, czas ich trwania, kolejność oraz łączące je sakkady.

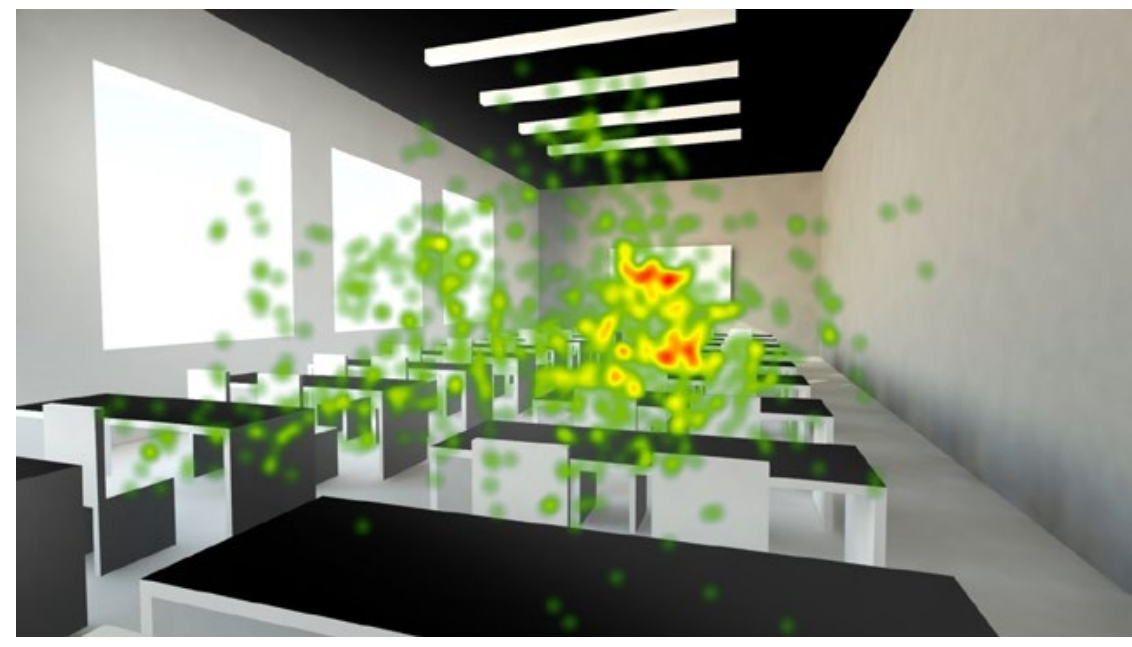

Ryc. 1. Przykładowa mapa cieplna punktów charakterystycznych o najdłuższym czasie obserwacji przez uczestników badania eye-trackingowego.

źródło: Tuszyńska-Bogucka et al., 2018

W wyniku realizacji badania eye trackingowego można uzyskać informacje o tym, gdzie patrzy użytkownik, jakie elementy są zauważane jako pierwsze, które przyciągają najwięcej uwagi, a które są ignorowane, a także to, jakie elementy sprawiają mu problem - co może wynikać z dłuższych czasów fiksacji (Garczarek, Bąk, 2016 ${ }^{26}$ ).

Oprócz tego danymi najczęściej analizowanymi są tzw. mapy ciepła. Ideą tej formy przekazywania danych jest użycie poszczególnych barw dla obszarów, które skupiają uwagę osób badanych (bardzo przystępna forma graficzna obszarów, na których użytkownicy skupiali swój wzrok). I tak barwa czerwona oznacza obszary, które cechowały się najdłuższym czasem i najwyższą częstotliwością obserwacji, barwa żółta nieco mniejszym, a zielona - najmniejszym zainteresowaniem. Obszary bez żadnej barwy oznaczają miejsca pominięte. Inne analizowane informacje to tzw. AOI - obszary zainteresowań (Jordanowski, Chojnacki, 2009 ${ }^{27}$ ), a więc te fragmenty

26 Garczarek-Bąk U, użyteczność badań eye trackingowych w pomiarze utajonych determinant zachowań zakupowych nabywców. Ekonometria 2016, 3(53): 54-71.

27 Jordanowski P, Chojnacki W, Obszary zainteresowań (ang. area of interest - AOI) jako metoda analizy wyników badania eye tracking. Interfejs użytkownika - Kansei w praktyce 2009, 107-118. Retrieved from https://repin.pjwstk.edu.pl/xmlui/bitstream/handle/186319/128/ kansei2009_Jardanowski_Chojnacki.pdf?sequence=1 [access: 2018-11-12]. 
bodźca wizualnego, które budzą szczególne zainteresowanie (szczególnie użyteczne np. w badaniach, które elementy prezentowanego obrazu budzą największe zainteresowanie). Na rys. 1 zaprezentowano jako przykład aktywność oczu (mapa cieplna) w trakcie oglądania materiału eksperymentalnego (Tuszyńska-Bogucka et al., 2018) w badaniach nad znaczeniem emocjonalnym przestrzeni edukacyjnej.

Wiedza o tych procesach, a w szczególności informacja na temat czasów fiksacji, prędkości, liczbie oraz częstotliwości ruchów sakkadycznych, może być niezwykle cennym materiałem ułatwiającym zrozumienie mechanizmów percepcji wzrokowej. Dodatkowe elementy, takie jak np. aktywność źreniczna mogą z kolei przyczynić się do pogłębienia wiedzy na temat efektu emocjonalnego prezentowanego obrazu (Partala et al., $2000^{28}$; Onorati et al., $2013^{29}$ ).

Niniejsze omówienie nie wyczerpuje całości zagadnienia, jakim jest wielość i złożoność dostarczanego przez eye tracking danych, sygnalizuje jedynie ich potencjalną wartość w badaniach różnego typu.

\section{Eye tracking w urbanistycznych badaniach eksperymentalnych}

Obecnie metoda eye trackingu zaczyna być stosowana także w sztukach pięknych (malarstwie, sztukach audiowizualnych), gdzie najciekawsze zastosowania dotyczą okoruchowych korelatów piękna (Francuz, 2013 ${ }^{30}$; Kędziora, 2016 $6^{31}$ ), uniwersalności języka abstrakcji (Brinkmann et al., 2014²) oraz analizy performance (Kuś, 2015). Zdaniem autorów artykułu metoda ta może być także z powodzeniem stosowana w badaniach nad krajobrazem kulturowym w aspekcie urbanistyczno-architektonicznym oraz ogólnie w badaniach nad przestrzenią architektoniczną pod kątem m.in. jej jakości oraz rodzaju wywieranego efektu (Kabaja, Kruka, 201733; Rusnak, Szewczyk, 2018 ${ }^{34}$ ), nie tylko estetycznego, ale także psychologicznego. Postulat ten opiera się na twierdzeniu, iż dobór optymalnego rozwiązania powinien opierać się nie na subiektywnych preferencjach, a na poszerzonych analizach interdyscyplinarnych zespołów badawczych (Rusnak, Szewczyk, 2018).

Wydaje się, że eye tracking może więc stanowić metodę urbanistycznych badań eksperymentalnych. Współczesne badania w tym obszarze dotyczą głównie kontroli równowagi w otoczeniu urbanistycznym, których efektem są wskazania przykładów zmian i interwencji, których konsekwencje można zbadać przy użyciu eye trackingu (Rusnak, Szewczyk, 2018). Dotyczy to zarówno układu przestrzennego wnętrz, wpływu architektury na zachowania i orientację osób weń przebywających, zbadania skuteczności oznaczeń ewakuacyjnych czy efektów oddziaływania przestrzeni architektonicznej na rożne grupy odbiorców. Podsumowując, w tym obszarze badań metoda eye trackingu może być pomocna w wyjaśnieniu braku pełnego zrozumienia między ogółem odbiorców i użytkowników przestrzeni architektonicznych, a środowiskiem profesjonalistów (Rusnak, 201 ${ }^{35} 7$; Rusnak, Szewczyk, 2018).

Obecnie zaznacza się także silne zapotrzebowanie, aby lepiej konceptualizować projekty technologiczne i konteksty przestrzenne użytkowania rozmaitych przestrzeni - np. szkół, szpitali czy urzędów. Oznacza to, że powinniśmy bardziej bezpośrednio angażować się w ich projektowanie i ocenianie, aby w ten sposób postrzegać przestrzeń jako integralną część „technologii", która może pośredniczyć w rozmaitych procesach - np. uczeniu

28 T. Partala, M. Jokiniemi, V. Surakka, "Pupillary responses to emotionally provocative stimuli" in Proceedings of the 2000 symposium on Eye tracking research and applications. ACM, pp. 123-9, 2000.

29 F. Onorati, R. Barbieri, M. Mauri, V. Russo, L. Mainardi, "Characterization of affective states by pupillary dynamics and autonomic correlates," Frontiers in Neuroengeenering, vol. 6, no. 9, eCollecton 2013. Retrieved from https://www.ncbi.nlm.nih.gov/pmc/articles/PMC3818468/ [access: 2018-11-10]

30 Francuz P., Imagia - w kierunku neurokognitywnej teorii obrazu. Lublin. Retriewed from: http://afterimagia.pl/book/ system-kadrowaniasceny-wizualnej/(access: 2018-05-11].

31 Kędziora Ł, Wykorzystanie badań okulograficznych w historii sztuki, [w:] Badania i Rozwój Młodych Naukowców w Polsce. Nauki humanistyczne i społeczne, tom 1, Poznań 2016, s. 25-32.

32 Brinkmann H, Commare J, Leder H, et al. Abstract Art. As a universal language? Leonardo 47/3, 256-257.

33 Kabaja B, Kruka M, Możliwości wykorzystania metody eye tracking do badań nad historyczną przestrzenią architektoniczną w kontekście jej postrzegania przez użytkowników (na przykładzie Rabki-Zdroju). Część 1. Uwagi wstępne. Wiadomości Konserwatorskie/Journal of Heritage Conservation 2017, 52: 74-85

34 Rusnak M, Szewczyk J, Okulograf jako innowacyjne narzędzie konserwatorskie. Propozycja poszerzenia zakresu badań, dotyczących dziedzictwa architektury i urbanistyki. Wiadomości Konserwatorskie/Journal of Heritage Conservation 2018, 54: 25-35.

35 Rusnak M. Eye tracker as a reserch tool for studying architectural heritage. In: V International Polish Eye Tracking Conference, Lublin, 2017 23-24 
się. Wiedza, jak bardzo przestrzeń i funkcjonowanie jednostki (w każdym obszarze, a więc funkcjonowanie emocjonalne, intelektualne czy społeczne) są ze sobą powiązane wciąż nie jest pełna, stąd wynika konieczność badań nad tym zagadnieniem i określeniem kierunków w badaniach nad projektowaniem i oceną przestrzeni (Woolner et al., 20076; Tuszyńska-Bogucka et al., 2018). Metoda pomiaru eye trackingowego wydaje się być interesującym sposobem badania reakcji na rozmaite typy wnętrz i przestrzeni, co daje szansę na ich lepsze zaprojektowanie w bardzo wstępnej fazie realizacji projektu architektonicznego, a więc już na etapie konceptualizacji. Stwarza to dodatkową wartość aplikacyjną, pozwalającą zmniejszyć ewentualne koszty. Warto tu wymienić np. serię eksperymentów nad diagnozą charakteru przestrzeni szkolnych czy szpitalnych (Meyer, 1992; Reiling, 2006; Painter et al., 2013; Skałbania-Gretkowski, 2015; Szewczenko-Benek, 2015 ${ }^{37}$ ), także z użyciem eye trackingu (Tuszyńska-Bogucka et al., $2018^{38}$ ). Jest to nawiązanie do poprzedniego nurtu badań, gdyż podobnie tu zapis i analiza procesu patrzenia na dany obiekt czy przestrzeń mogłyby stanowić klucz, najpierw do zrozumienia tego, jak człowiek wizualnie odbiera przestrzeń, a następnie do optymalnego jej aranżowania - podkreślenia elementów istotnych i wycofania dysharmonijnych (Rusnak, Szewczyk, 2018), zapewnienia ergonomii kolorystycznej i przestrzennej, itp. Może to mieć zastosowanie w projektowaniu przestrzeni architektonicznych, także takich, jak szkoła, szpital czy też budynki użyteczności publicznej, a więc przestrzeni, odgrywających ogromną rolę w kształtowaniu przyjaznego środowiska życia i funkcjonowania jednostki i społeczeństwa.

\section{Literatura}

[1] A.M. Szewczenko, I.D. Benek, „Współczesne tendencje w projektowaniu oddziału geriatrycznego - komponenty przestrzeni przyjazne starszemu pacjentowi," Acta Universitatis Lodziensis, Folia Oeconomica, vol. 4, no. 315, pp. 147-157, 2015.

[2] B. Skałbania, A. Gretkowski, „Szpital jako miejsce (nie) przyjazne dziecku - rola proksemiki w procesie leczenia,” Rocznik Towarzystwa Naukowego Płockiego, vol. 8, pp. 411-426, 2015.

[3] Błasiak W, Godlewska M, Rosiak R, Wcisło D, Eye tracking. Nowe możliwości eksperymentalne w badaniach edukacyjnych. Edukacja-Technika-Informatyka 2013, 4(1): 481-488.

[4] Brinkmann H, Commare J, Leder H, et al. Abstract Art. As a universal language? Leonardo 47/3, 256-257.

[5] D.J. Mayer, "Hospital design of the future--healing environments," California Hospital Medical Center, vol. 6, no. 3 (May-Jun), pp. 8-11, 1992.

[6] Duchowski A.T., 2007, Eye tracking methodology: Theory and practice. Second Edition. London: Springer-Verlag.

[7] F. Onorati, R. Barbieri, M. Mauri, V. Russo, L. Mainardi, "Characterization of affective states by pupillary dynamics and autonomic correlates," Frontiers in Neuroengeenering, vol. 6, no. 9, eCollecton 2013. Retrieved from https://www.ncbi. nlm.nih.gov/pmc/articles/PMC3818468/ [access: 2018-11-10]

[8] Francuz P., Imagia - w kierunku neurokognitywnej teorii obrazu. Lublin. Retriewed from: http://afterimagia.pl/book/ system-kadrowania-sceny-wizualnej/(access: 2018-05-11].

[9] Garcia-Blanco, A., Salmerón, L., Perea, M., Livianos, L., 2014. Attentional biases toward emotional images in the different episodes of bipolar disorder: an eye-tracking study. Psychiatry Res. 215 (3), 628-633.

[10] Garczarek-Bąk U, użyteczność badań eye trackingowych w pomiarze utajonych determinant zachowań zakupowych nabywców. Ekonometria 2016, 3(53): 54-71.

36 P. Woolner, E. Hall, K. Wall, D. Dennison, "Getting together to improve the school environment: user consultation, participatory design and student voice," Improving Schools, vol. 10, no. 3, pp. 233-248, 2007.

37 S. Painter, J. Fournier, C. Grape, P. Grummon, J. Morelli, S Whitmer, and J. Cevetello, "Research on Learning Space Design: Present State, Future Directions," Society for College and University Planning, 2013.

B. Skałbania, A. Gretkowski, "Szpital jako miejsce (nie) przyjazne dziecku - rola proksemiki w procesie leczenia," Rocznik Towarzystwa Naukowego Płockiego, vol. 8, pp. 411-426, 2015.

M. Grzymała-Kozłowski, A. Ruszkowska, "Architektura zdrowia," Ogólnopolski System Ochrony Zdrowia, vol. 7, pp. 35-38, 2013.

D.J. Mayer, "Hospital design of the future-healing environments," California Hospital Medical Center, vol. 6, no. 3 (May-Jun), pp. 8-11, 1992.

J. Reiling, "Safe design of healthcare facilities," Quality \& Safety in Health Care, vol. 15, pp. 34-40, 2006.

A.M. Szewczenko, I.D. Benek, "Współczesne tendencje w projektowaniu oddziału geriatrycznego - komponenty przestrzeni przyjazne starszemu pacjentowi," Acta Universitatis Lodziensis, Folia Oeconomica, vol. 4, no. 315, pp. 147-157, 2015.

38 Tuszyńska-Bogucka W, Borys M, Dzieńkowski M, Kwiatkowski B, Kocki W, Pełka J, Bogucki J, Use Of Eye Tracking For Designing of Learning Spaces. ICERI2018 (11th Annual International Conference of Education, Research and Innovation), 12-14 Of November 2018, Seville, Spain. 
[11] Gillespie-Smith, K., Fletcher-Watson, S., 2014. Designing AAC systems for children with autism: evidence from eye tracking research. Augment. Altern. Commun. 30 (2), 160-171.

[12] H. Mruk, Neuromarketing jako obszar badań interdyscyplinarnych. W: Współczesny marketing. Trendy. Działania, G. Sobczyk (red.), PWE, Warszawa 2008, s. 97.

[13] Harezlak, K., Kasprowski, P., Application of eye tracking in medicine: A survey, research issues and challenges. Comput Med Imaging Graph (2017), http://dx.doi.org/10.1016/j.compmedimag.2017.04.006

[14] Horsley M., 2014, Eye Tracking as a Research Method in Social and Marketing Applications, [in:] Current Trends in Eye Tracking Research, Horsley M., Toon N., Knight B., Reilly R. (eds.), Springer International Publishing, Switzerland.

[15] https://repin.pjwstk.edu.pl/xmlui/bitstream/handle/186319/128/kansei2009_Jardanowski_Chojnacki.pdf?sequence=1 [access: 2018-11-12].

[16] J. Reiling, "Safe design of healthcare facilities," Quality \& Safety in Health Care, vol. 15, pp. 34-40, 2006.

[17] Jordanowski P, Chojnacki W, Obszary zainteresowań (ang. area of interest - AOI) jako metoda analizy wyników badania eye tracking. Interfejs użytkownika - Kansei w praktyce 2009, 107-118. Retrieved from

[18] Josephson, S., Holmes, M.: Age differences in visual search for information on web pages. In: Eye Tracking Research \& Application. Proceedings of the 2004 symposium on Eye tracking research \& applications, San Antonio, TX, p. 62 (2004).

[19] Kabaja B, Kruka M, Możliwości wykorzystania metody eye tracking do badań nad historyczną przestrzenią architektoniczną w kontekście jej postrzegania przez użytkowników (na przykładzie Rabki-Zdroju). Część 1. Uwagi wstępne. Wiadomości Konserwatorskie/Journal of Heritage Conservation 2017, 52: 74-85

[20] Kaczmarek M., 2012, Mocne i słabe strony eye trackingu jako metody badania zachowań nabywców, [w:] Foresight w praktyce zarządzania przedsiębiorstwem. Analizy i studia przypadków, Borodako, K., Nowosielski M. (red.), Instytut Zachodni, Poznań.

[21] Kędziora Ł, Wykorzystanie badań okulograficznych w historii sztuki, [w:] Badania i Rozwój Młodych Naukowców w Polsce. Nauki humanistyczne i społeczne, tom 1, Poznań 2016, s. 25-32.

[22] Kraus, D., Horowitz-Kraus, T. (2014). The effect of learning on feedback - related potentials in adolescents with dyslexia: An EEG-ERP study. PLoS ONE, 9 (6)

[23] Law B, Atkins MS, Kirkpatrick AE, Lomax AJ, Mackenzie CL, Eye gaze patterns differentiate novice and experts in a virtual laparoscopic surgery training environment. Conference: Proceedings of the Eye Tracking Research \& Application Symposium, ETRA 2004, San Antonio, Texas, USA, March 22-24, 2004. Retriewed from https://www.researchgate.net/ publication/220811148_Eye_gaze_patterns_differentiate_novice_and_experts_in_a_virtual_laparoscopic_surgery_training_environment [access: 2018-11-12].

[24] M. Grzymała-Kozłowski, A. Ruszkowska, „Architektura zdrowia,” Ogólnopolski System Ochrony Zdrowia, vol. 7, pp. 35-38, 2013.

[25] Manelis, A., Reder, L.M. (2012). Procedural learning and associative memory mechanism contribute to contextual cueing: Evidence from fMRI and eye-tracking. Learning \& Memory, 19, 527-534.

[26] Merkisz J, Markowski J, Fuć P, Galant M, Przegląd metod pomiaru obciążenia zadaniowego operatora w badaniach z wykorzystaniem symulatorów. Logistyka 2015, 3: 3188-3194.

[27] O. Pilipczuk, Zastosowanie wizualizacji kognitywnych w podejmowaniu decyzji biznesowych, w: Wiedza i technologie informacyjne: nowe trendy badań i aplikacji, red. T. Turek, D. Jelonek, WWZPCz, Częstochowa 2013, s. 86-101; O. Pilipczuk, D. Eidenzon, The application of cognitive computer graphics to economic data exploration, „Journal of Automation, Mobile Robotics \& Inteligent Systems" 2013, vol. 7(3), s. 3-9.

[28] P. Woolner, E. Hall, K. Wall, D. Dennison, "Getting together to improve the school environment: user consultation, participatory design and student voice," Improving Schools, vol. 10, no. 3, pp. 233-248, 2007.

[29] Paśko I, Eyetrackingowe badania we wczesnej edukacji przyrodniczej. Pedagogika Przedszkolna i Wczesnoszkolna 2017, 5, 2/1 (10/1): 205-215.

[30] Pilipczuk O, Technologie eye-tracking w analizie danych medycznych. Roczniki Kolegium Analiz Ekonomicznych / Szkoła Główna Handlowa 2014, 35: 323-337.

[31] Piotrowska I, Okulografia w badaniach postrzegania i konstruowania wiedzy geograficznej. Prace Komisji Edukacji Geograficznej 2014, t. 3, s. 175-189.

[32] R.K. Ohme, Biometryczny przełom w marketingu. Jak dzięki wykorzystaniu badań biometrycznych podnosić skuteczność komunikacji marketingowej i budować trwałe, emocjonalne relacje z klientami, "Harvard Business Review Polska” 2011, nr 7/8. 
[33] Rusnak M, Szewczyk J, Okulograf jako innowacyjne narzędzie konserwatorskie. Propozycja poszerzenia zakresu badań, dotyczących dziedzictwa architektury i urbanistyki. Wiadomości Konserwatorskie/Journal of Heritage Conservation 2018, 54: 25-35.

[34] Rusnak M. Eye tracker as a reserch tool for studying architectural heritage. In: V International Polish Eye Tracking Conference, Lublin, 2017, 23-24.

[35] S. Painter, J. Fournier, C. Grape, P. Grummon, J. Morelli, S Whitmer, and J. Cevetello, "Research on Learning Space Design: Present State, Future Directions," Society for College and University Planning, 2013.

[36] Studer, B., Koeneke, S., Blum, J., Jäncke, L. (2010). The effects of practice distribution upon the regional oscillatory activity in visuomotor learning. Behavioral and Brain Functions, 6 (8).

[37] T. Partala, M. Jokiniemi, V. Surakka, "Pupillary responses to emotionally provocative stimuli" in Proceedings of the 2000 symposium on Eye tracking research and applications. ACM, pp. 123-9, 2000.

[38] Tullis T.S. (2007) Older Adults and the Web: Lessons Learned from Eye-Tracking. In: Stephanidis C. (eds) Universal Acess in Human Computer Interaction. Coping with Diversity. UAHCI 2007. Lecture Notes in Computer Science, vol 4554. Springer, Berlin, Heidelberg

[39] Tuszyńska-Bogucka W, Borys M, Dzieńkowski M, Kwiatkowski B, Kocki W, Pełka J, Bogucki J, Use Of Eye Tracking For Designing of Learning Spaces. ICERI2018 (11th Annual International Conference of Education, Research and Innovation), 12-14 Of November 2018, Seville, Spain.

[40] V. Raudonis, R. Simutis, G. Narvydas, Discrete eye tracking for medical applications, 2nd International Symposium on Applied Sciences in Biomedical and Communication Technologies, 2009, s. 1-6.

[41] Wang, H-S., Chen, Y-T., Lin, C-H. (2014). The learning benefits of using eye trackers to enhance the geospatial abilities of elementary school students. British Journal of Educational Technology, 45 (2), 340-355.

[42] Wawer, R. (2014). Eyetracking w przestrzeniach edukacji medialnej. Lublin: Lubelskie Towarzystwo Naukowe.

[43] Wąsikowska B, Eye tracking w badaniach marketingowych. Zeszyty Naukowe Uniwersytetu Szczecińskiego Studia Informatica 2016, 863(36): 177-192.

[44] Wedel M., Pieters R., 2008, A Review of Eye-Tracking Research in Marketing, [w:] Review of Marketing Research, Malhotra N.K. (eds.), M.E. Sharpe, Inc., Armonk, New York, London, England.

[45] Wilson MR, Vine SJ, Bright E, Masters RS, Defriend D, McGrath JS. Gaze training enhances laparoscopic technical skill acquisition and multi-tasking performance: a randomized, controlled study. Surg Endosc. 2011;25(12):3731-9.

[46] Yang, Q., Wang, T., Su, N., Xiao, S., Kapoula, Z., 2013. Specific saccade deficits inpatients with Alzheimer's disease at mild to moderate stage and in patientswith amnestic mild cognitive impairment. Age 35 (4), 1287-1298.

\title{
Eyetracking as a method to create new possibilities in urbanistic experimental research
}

\begin{abstract}
Eye tracking, and thus the method of testing oculomotor activity among various applications, also creates a unique opportunity for research in experimental urbanization. Due to the large amount of data provided by this method, it not only shows how to look at buildings and the surrounding space, but also the emotional reactions that they cause in the recipient, contributing to the creation of so-called. a friendly architectural environment. Assuming interdisciplinary cooperation and discussion of specialists in the fields of psychology, architecture and computer science, it seems that contemporary oculography can become a tool harmoniously integrating activities, which in turn increases both knowledge about the effect of architectural space on a human being, and how to plan it, that it actively contributes to the optimization of the living conditions of modern man based on objective data.
\end{abstract}

